\title{
The Extent of Heat on Health and Sustainable Farming in Ghana -Bawku East
}

\author{
Frimpong, K. ${ }^{1}$, Oosthuizen, J. $^{2} \&$ Van Etten E. J. ${ }^{1}$ \\ ${ }^{1}$ School of Natural Science, Edith Cowan University, Perth, Australia \\ ${ }^{2}$ School of Exercise and Health Sciences, Edith Cowan University, Perth, Australia \\ Correspondence: Kwasi Frimpong, School of Natural Science, Edith Cowan University, Perth, Australia. E-mail: \\ Frimpongk@hotmail.com; frimyaam@gmail.com
}

Received: April 10, 2014 Accepted: June 12, 2014 Online Published: June 19, 2014

doi:10.5539/sar.v3n3p56 URL: http://dx.doi.org/10.5539/sar.v3n3p56

\begin{abstract}
Little is known about the health effects of heat in outdoor work and appropriate work and rest schedules for farmers working in developing countries. As temperatures continue to increase in tropical regions, such as Northern Ghana, it is necessary to evaluate how farmers experience and respond to high heat exposures. In this study, WBGT (Wet Bulb Globe Temperature) estimates and the ISO work / rest standards were applied to a cohort of farmers in the rural areas of Bawku East, Northern Ghana, to assess how farmers respond to high heat and how much they rest to protect their health, as well as the level of heat on their productivity. WBGT data was recorded over a period of 6 months among vegetable, cereals, and legume farmers. The ISO proposed and actual rest regimes observed by farmers in the same time period were evaluated. In the dry season the dry bulb temperature rose as high as $45^{\circ} \mathrm{C}$, while during the humid months of March and April WBGT rose to levels as high as $34^{\circ} \mathrm{C}$. Farmers worked for nine hours a day during these hot periods with insufficient rest, which has adverse consequences on their health and productivity.
\end{abstract}

Keywords: climate change, heat stress, health, agricultural productivity, farmers, tropical agriculture

\section{Introduction}

Working during periods of high temperatures, particularly in full sunshine, can have serious health consequences on farmers and can reduce their productivity by decreasing work comfort and performance (Kjellstrom, 2009; Parsons, 2003). Heat affects health and productivity but such impacts would be expected to worsen under climate change unless proper adaptation measures are instituted (Kjellstrom, 2000). Studies on heat stress and its physiological impact are scanty in the developing world. In contrast, in the developed world, copious research on heat and its physiological threat on human health are prominent in both indoor and outdoor occupational health research (Ebi, Smith, \& Burton, 2006; Parsons, 2003). As a result there are occupational safety guidelines to minimize heat stress in many indoor occupations such as manufacturing and other services industries (Kjellstrom, Butler, Lucas, \& Bonita, 2010). In developing countries there is much concern over the increased risk of heat stress on farmers as a result of rising outdoor temperatures, particularly as many farmers spend not less than eight hours every day in the full sunshine to cultivate or harvest (Kjellstrom, Gabrysch, Lemke, \& Dear, 2009; Kjellstrom, Kovats, Lloyd, Holt, \& Tol, 2009). The IPCC predictions indicate that sub-Saharan Africa is expected to attain a sustained warming above the global average prediction and the poorest in the region would be the most at risk of the warming impact (Haines, Kovats, Campbell-Lendrum, \& Corvalán, 2006). The emergence of warming predominantly in the African region (IPCC, 2007b) requires improved adaptation that can maintain the wellbeing and work performance of workers ( Kjellstrom, 2000).

Over the last fifty years, a one degree Celsius rise in average temperature predominantly in Northern Ghana has created a substantial increase in heat exposure (McSweeney, 2012; Frimpong et al., 2014). The increase in temperature has resulted in some 50 more hot days and 80 hot nights every year (McSweeney, 2012) which makes the situation disturbing and in need of remedial action. The plight of residents in Northern Ghana is made worse by the "harmattan" dry winds that come from the Sahara desert during November to February in contrast to the south- west monsoon winds that blow from the Atlantic Ocean to cool down people in the southern part of Ghana at this time of the year (Climate vulnerability monitor, 2012). Temperatures are projected to be extreme in the Northern Ghana by the year 2020 (EPA, 2007). This demands the need to undertake hourly assessment of 
heat for government led response. The rise in heat exposure in Northern Ghana has created a negative effect on the health of the resident population and its consequent impact on agriculture which is the key occupation of the people in the area (Climate vulnerability monitor, 2012). Heat stress is prevalent since almost all the farmers work during the most heat extreme period of the day and this affects their productivity and impacts on the sustainability of farming (Climate vulnerability monitor, 2012). Studies that establish the relationships between human physiology, state of the climate and its impact on health and work capacity are well expatiated in literature of physiology, occupational health and ergonomics (Bridger, 2003; Parsons, 2003). As a result, extensive heat exposure has the tendency to reduce work performance since the human body naturally reacts to heat by reducing physical work activity in heat prone environments (Kjellstrom, Holmer, \& Lemke, 2009; Parsons, 2003).

Many researchers have concentrated their efforts on estimating global averages of temperature which fail to depict the real extent of local heat exposure and local rise in temperature (Frimpong, Van Etten, \& Oosthuizen, 2014; Kjellstrom, Lemke, \& Otto, 2013). The level of local climatic change will differ in each locality with regard to geographic and meteorological conditions unique to each area (Kjellstrom et al., 2009). The upsurge of local ambient temperature denotes that the people living in that environment will be exposed to high heat (Kjellstrom et al., 2009), and in hot tropics this could affect health and the productivity of outdoor workers (Kjellstrom, 2000; Kjellstrom et al., 2009).

In Pusiga of Northern Ghana, a large number of farmers live in round houses which have no adequate ventilation (Figure 2), though the grass used as roofing relatively cool down the temperature in the rooms as compared to roofing sheets. As in most developing countries more than 70 percent of farming work is labor intensive (FAO, 1987) as can be seen in Figure 1, and during periods of high temperatures, this could have a deleterious effect on agricultural productivity, sustainable farming and farmers' health (Kjellstrom et al., 2009). Studies have indicated that there is increased metabolic heat loads characterized with heavy work performance (Maté \& Oosthuizen, 2011). Using shovel to scoop loose sand could be measured within the range of $266 \mathrm{~W} \cdot \mathrm{m}^{2}$ and $407 \mathrm{~W} \cdot \mathrm{m}^{2}$ (Bethea, Bobo, \& Ayoub, 1980; Leithead \& Lind, 1964). In the same vein performing a task of drilling falls within 217 W. $\mathrm{m}^{2}$ to $290 \mathrm{~W} . \mathrm{m}^{2}$ (Mate et al., 2007). Continuous work with shovel by a person of $75 \mathrm{~kg}$ without rest or cooling can increase core body temperature (Maté \& Oosthuizen, 2011). In categorization of task by ISO 7243, working with shovel, pick axe, drilling and cutlass are likely to fall within high and very high metabolic rate and work intensities (ISO, 1989). Heat related illness is prone to occur in high heat exposure where core body temperature exceeds $39^{\circ} \mathrm{C}$ (Donoghue, Sinclair, \& Bates, 2000). Such level of heat can create dizziness to fatal heat stroke (Coris, Ramirez, \& Van Durme, 2004), during the performance of a task in the regime of high and very high work intensities in excessive heat environment without cooling or rest (Nybo, 2008).

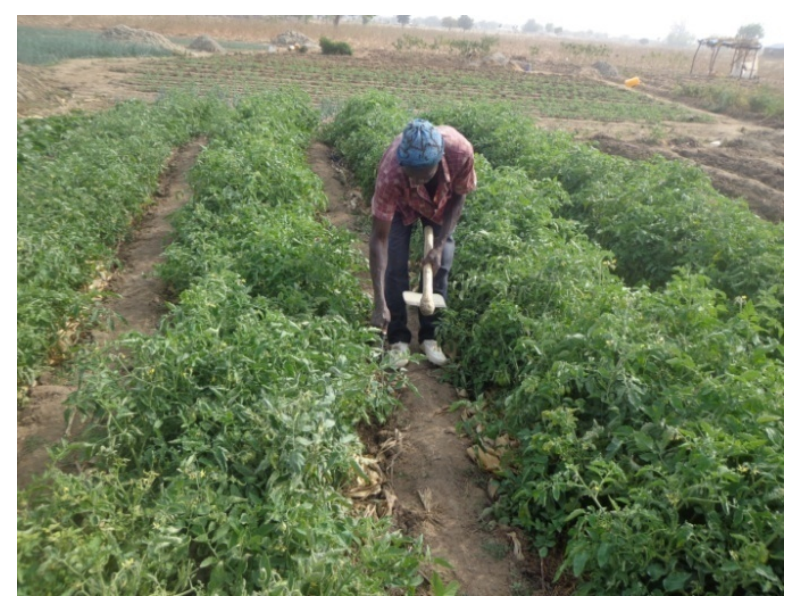

Figure 1. A picture of labour intensive method of farming in Pusiga, (Bawku East) of Northern Ghana

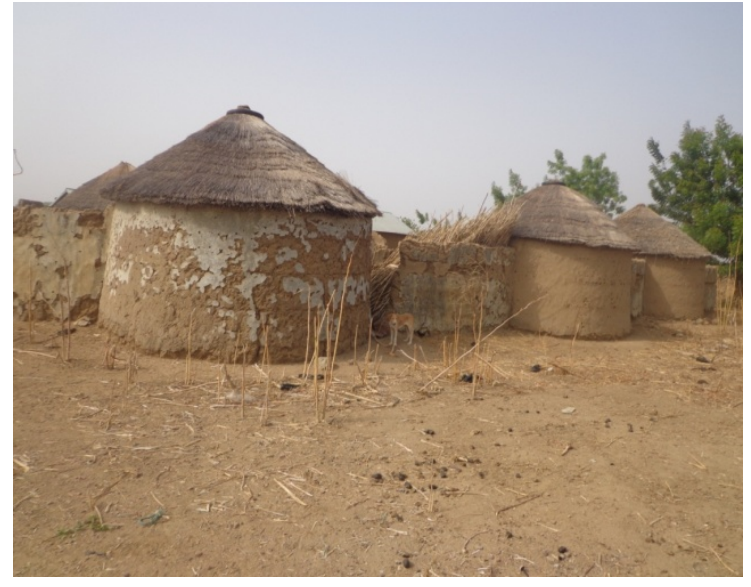

Figure 2. Typicalhouseswith inadequate ventilationin Pusiga, (Bawku East) of Northern Ghana

This paper used Wet Bulb Globe Temperature (WBGT) to illustrate occupational heat stress on the people of Pusiga in Bawku East of the Upper East part of Ghana where temperature reaches as high as 45 degrees Celsius (Frimpong et al., 2014; Laux, Kunstmann, \& Bárdossy, 2008). The purpose of the study is to undertake a 
preliminary investigation of the extent of heat stress on outdoor and indoor working and living areas of farmers respectively. The underpinning factor of the study is to serve as a methodological template for a larger study of heat stress on farmers covering the entire year. The WBGT is predominantly used by the Occupational Safety and the Health Administration of United States of America and the US Army to assess health related hazards from heat exposure on outdoor activities (Occupational Safety and Health Admnistration (OSHA), 1999; US Army center for Health Promotion and Preventive Medicine USACHPPM, 2003). The instrument and the index are known as WBGT. This index shows the level of heat exposure to which workers are exposed. It also regulates work and rest for the safety of workers health and avoidance of heat related injuries. Many outdoor occupations have adopted this heat index to regulate work and rest in many physically demanding activities in heat exposed environment. In this present study WBGT index is applied to assess the level of heat exposure on farmers who work outdoor in Pusiga of North East Ghana. The average hourly trend of WBGT in January, February, March, April, May and June (2013) are illustrated. January to May months fall within the dry season while June commences the wet season (Laux et al., 2008). Peak of highest temperature occur in the months of March, April and May (Frimpong et al., 2014). As a result of Climate change, rainfall now generally starts in June or late May instead of early May (Frimpong et al., 2014; Laux et al., 2008). Results of interviews of residents in (2013) regarding impact of high temperature and heat on health and outdoor farming work were shown to present the situation of heat and temperature and its future implication on sustainable farming. This study is unique in that there is no published study that has taken climate change impact assessment on local farmers in Ghana with the aim of estimating current heat impact and its progress as temperature continuous to increase. This is innovative in that it employed instruments that can measure heat for a year without human interference as distinguished from Questemp (heat measuring device) instrument which demands the care and operation of human personnel.

\section{Method}

Heat monitoring equipment capable of recording readings every hour (Lascar EL USB temperature and humidity loggers) (Kjellstrom, Sabine Gabrysch et al., 2009; Pradhan et al., 2013) were used to measure temperature, relative humidity and dew point at the workplace of farmers in selected rural crops growing communities at (Pusiga) in Bawku East, of Northern Ghana. The instruments were placed in the shade to prevent direct exposure to sunshine and they were secured to a tree for the duration of the monitoring period ( 9 January -7 July). Computer software developed by Lemke (Lemke \& Kjellstrom, 2012) which is predominantly used in the 'High Occupational Temperature Health and Productivity Suppression' (HOTHAPS is a global program of assessing heat stress) program was used to calculate WBGT from the recordings of the EL lascar USB instrument.

A questionnaire developed by the HOTHAPS program was adapted and administered to a cohort of crop (legume, cereals, Vegetables) growing farmers in the study area $(\mathrm{n}=308)$ in order to elicit information related to their self-reported health status and the impact of heat on their day to day work activities. The questionnaire cohort was recruited from the farming communities of Pusiga, Binduri, and Manga. The survey was administered as part of a large study to gauge the levels of concern and knowledge that local communities have about the issues of heat and climate change. These data were correlated with environmental measurements from January to June, 2013. Farmers were selected through purposive sampling and random probability procedure based on the pre requisite that each participant lived in the rural area of Bawku East, which consists of a number of smaller farming communities, worked as a farmer and cultivated either cereal, vegetable or legume crops.

\section{Results}

\subsection{Environmental Data}

Figure 3 to 8 show mean hourly WBGT with the 95\% confidence interval. In all the six graphs average WBGT begins to rise early in the morning, reaching its peak in the early to mid afternoon, thus the WBGT reaches its peak during the working day and drops off at night.. The vulnerability of the participating farmers to the impact of heat exposure were severe and were exacerbated by the fact that they generally spent at least 8 hours per day engaged in manual labour in the sun. There were no shade in the fields and no air conditioned homes to rest in which is typical of African farming system as reported by food and Agricultural Organization (FAO, 1987). Figure 9 represents average WBGT for every hour from 7 January to 7 July 2013. Figure 10 represent average WBGT in an hour in each month.

Table1 represents the levels of community concern for the impact of heat on health. Table 2 represents the effects of heat on income and productivity while Table 3 represents the WBGT in ISO 7243 recommended work load and average work rest ratio. 


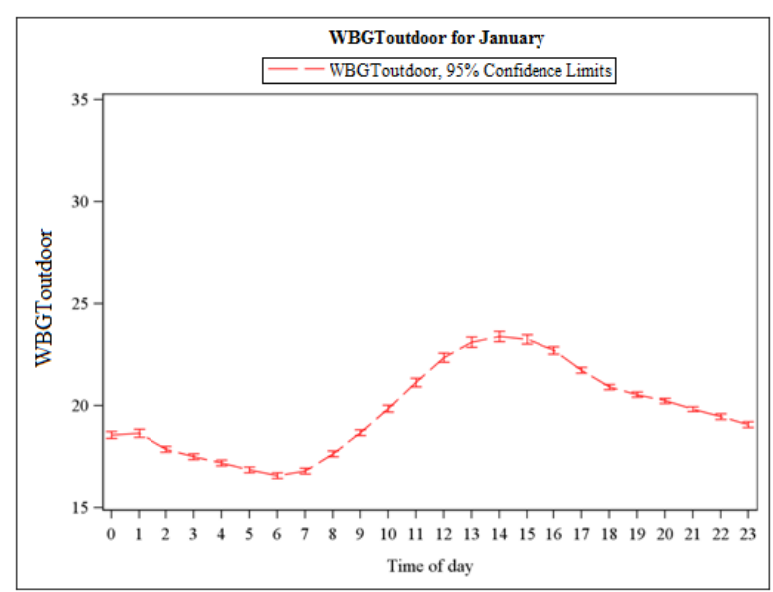

Figure 3. A pictorial representation of average WBGT in an hour in January within the $24 \mathrm{hr}$ cycle is explained in the graph

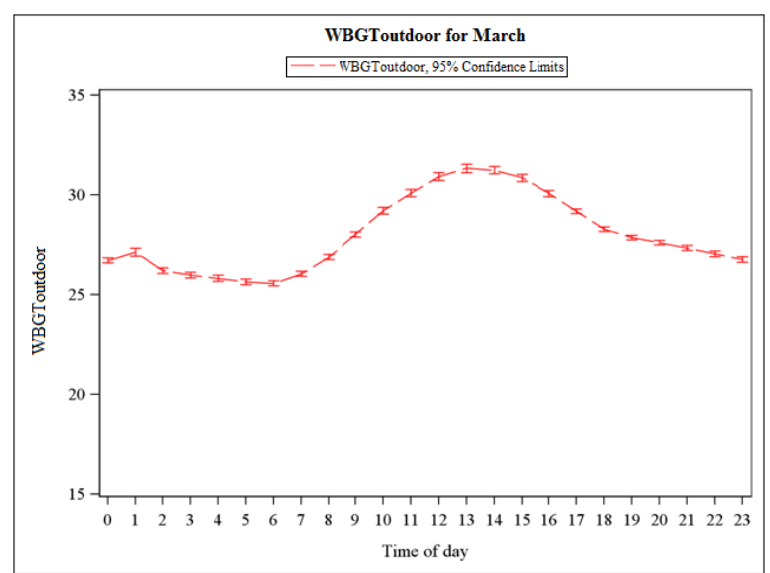

Figure 5. A pictorial representation of average WBGT in an hour in March within the $24 \mathrm{hr}$ cycle is explained in the graph

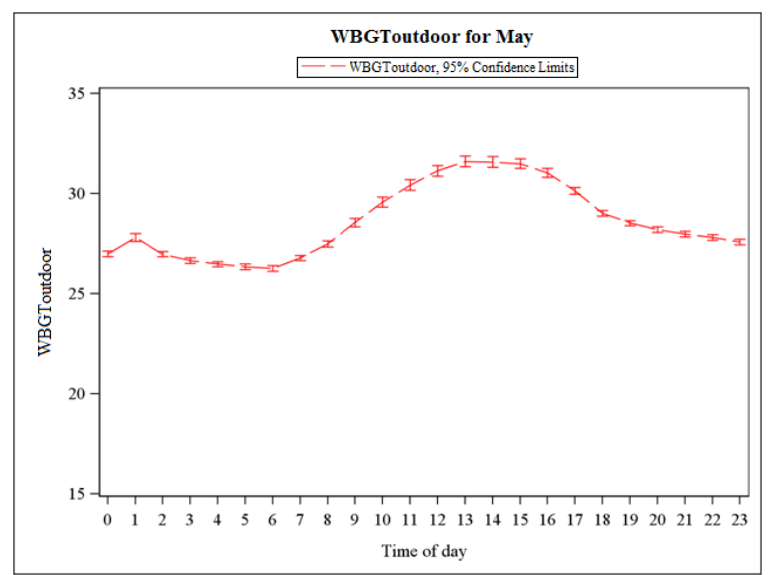

Figure 7. A pictorial representation of average WBGT in an hour in May within the $24 \mathrm{hr}$ cycle is explained in the graph

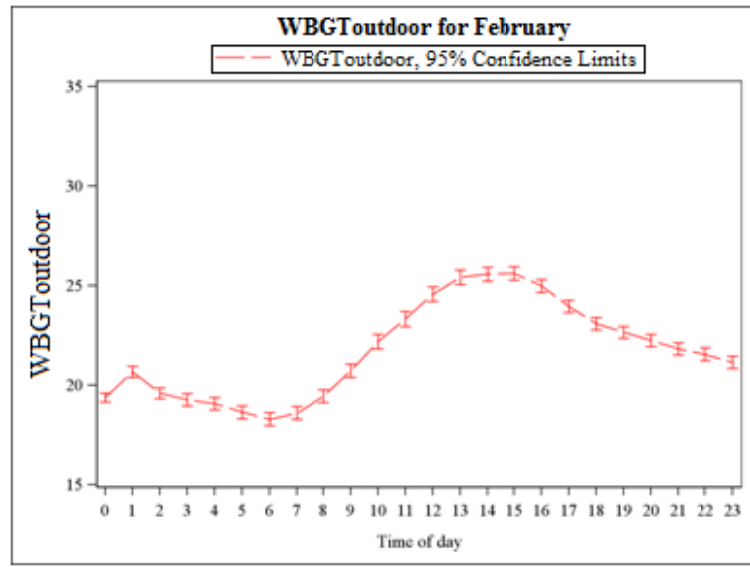

Figure 4. A pictorial representation of average WBGT in an hour in February within the $24 \mathrm{hr}$ cycle is explained in the graph

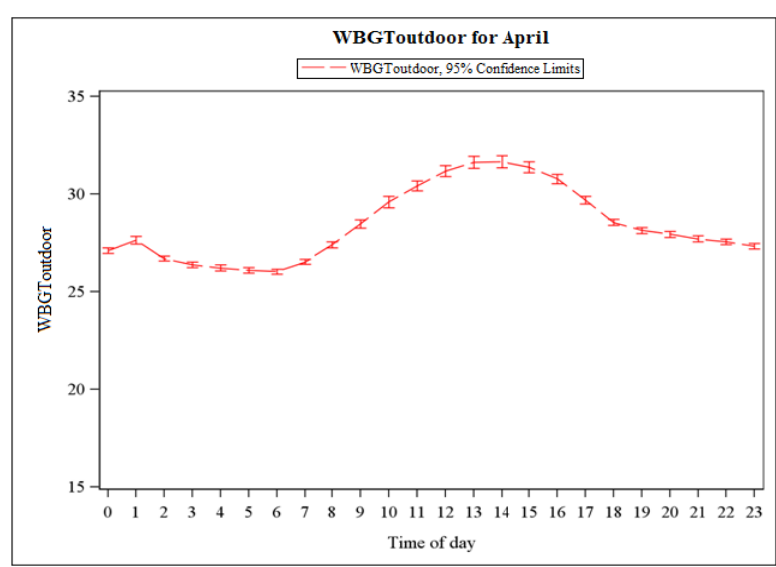

Figure 6. A pictorial representation of average WBGT in an hour in April within the $24 \mathrm{hr}$ cycle is explained in the graph

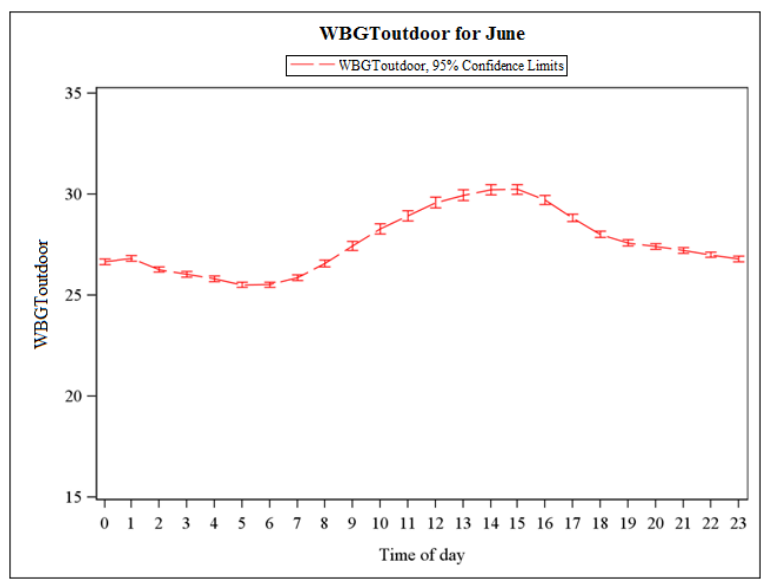

Figure 8. A pictorial representation of average WBGT in an hour in June within the $24 \mathrm{hr}$ cycle is explained in the graph 


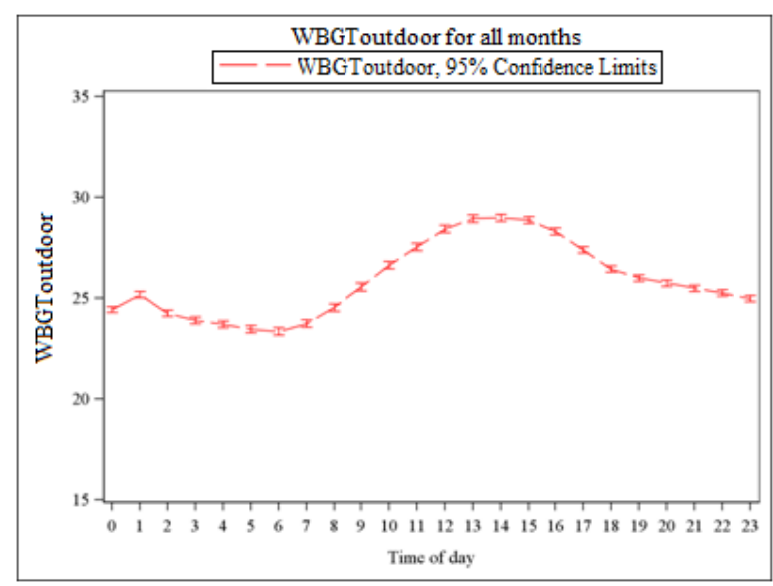

Figure 9. Average WBGT in an hour from 7 th January to $7^{\text {th }}$ July is illustrated below

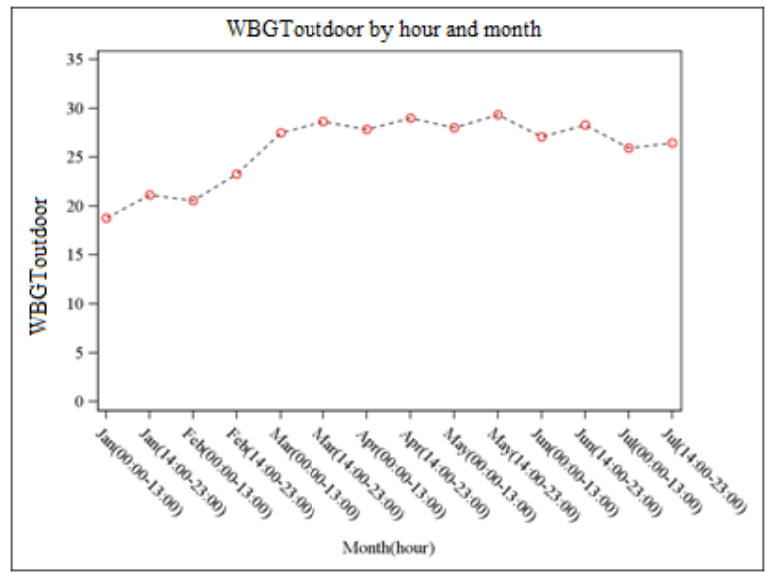

Figure 10. Average WBGT by hour and month

\subsection{Responses From Survey}

The survey data showed that farmers were concerned about heat and its impact on health.

Table 1. Concern of heat to health in Bawku East

\begin{tabular}{|c|c|c|c|c|c|c|c|c|c|c|c|c|c|c|}
\hline & \multicolumn{12}{|c|}{ Age group } & \multirow{2}{*}{\multicolumn{2}{|c|}{ Total }} \\
\hline & \multicolumn{2}{|c|}{ less than 20} & \multicolumn{2}{|c|}{$20-29$} & \multicolumn{2}{|c|}{$30-39$} & \multicolumn{2}{|c|}{$40-49$} & \multicolumn{2}{|c|}{$50-59$} & \multicolumn{2}{|c|}{$60+$} & & \\
\hline & Count & $\begin{array}{c}\% \\
\text { within } \\
\text { age }\end{array}$ & Count & $\begin{array}{c}\% \\
\text { within } \\
\text { age }\end{array}$ & Count & $\begin{array}{c}\% \\
\text { within } \\
\text { age }\end{array}$ & Count & $\begin{array}{c}\% \\
\text { within } \\
\text { age }\end{array}$ & Count & $\begin{array}{c}\% \\
\text { within } \\
\text { age }\end{array}$ & Count & $\begin{array}{c}\% \\
\text { within } \\
\text { age }\end{array}$ & Count & $\begin{array}{c}\% \\
\text { within } \\
\text { age }\end{array}$ \\
\hline $\begin{array}{c}\text { Concern of heat to } \\
\text { health }\end{array}$ & 13 & 92.9 & 45 & 91.8 & 56 & 94.9 & 49 & 89.1 & 88 & 98.9 & 36 & 97.3 & 287 & 94.7 \\
\hline yes & & & & & & & & & & & & & & \\
\hline NO & 1 & 7.1 & 4 & 8.2 & 3 & 5.1 & 6 & 10.9 & 1 & 1.1 & 1 & 2.7 & 16 & 5.3 \\
\hline Total & 14 & 100.0 & 49 & 100.0 & 59 & 100.0 & 55 & 100.0 & 89 & 100.0 & 37 & 100.0 & 303 & 100.0 \\
\hline
\end{tabular}


Table 2. Effects of heat on income and productivity

\begin{tabular}{|c|c|c|c|c|c|c|c|c|c|c|c|c|c|c|}
\hline & \multicolumn{12}{|c|}{ Age group } & \multirow{2}{*}{\multicolumn{2}{|c|}{ Total }} \\
\hline & \multicolumn{2}{|c|}{ less than 20} & \multicolumn{2}{|c|}{$20-29$} & \multicolumn{2}{|c|}{$30-39$} & \multicolumn{2}{|c|}{$40-49$} & \multicolumn{2}{|c|}{$50-59$} & \multicolumn{2}{|c|}{$60+$} & & \\
\hline & Count & $\begin{array}{c}\% \\
\text { within } \\
\text { age }\end{array}$ & Count & $\begin{array}{c}\% \\
\text { within } \\
\text { age }\end{array}$ & Count & $\begin{array}{c}\% \\
\text { within } \\
\text { age }\end{array}$ & Count & $\begin{array}{c}\% \\
\text { within } \\
\text { age }\end{array}$ & Count & $\begin{array}{c}\% \\
\text { within } \\
\text { age }\end{array}$ & Count & $\begin{array}{c}\% \\
\text { within } \\
\text { age }\end{array}$ & Count & $\begin{array}{c}\% \\
\text { within } \\
\text { age }\end{array}$ \\
\hline $\begin{array}{l}\text { Effects of Heat on } \\
\text { Income and } \\
\text { Productivity of } \\
\text { farmers }\end{array}$ & \multirow[b]{2}{*}{7} & \multirow[b]{2}{*}{50.0} & \multirow[b]{2}{*}{37} & \multirow[b]{2}{*}{72.5} & \multirow[b]{2}{*}{25} & \multirow[b]{2}{*}{41.7} & \multirow[b]{2}{*}{24} & \multirow[b]{2}{*}{43.6} & \multirow[b]{2}{*}{51} & \multirow[b]{2}{*}{56.0} & \multirow[b]{2}{*}{13} & \multirow[b]{2}{*}{35.1} & \multirow[b]{2}{*}{157} & \multirow[b]{2}{*}{51.0} \\
\hline $\begin{array}{l}\text { Affect Productivity } \\
\text { and Income by } \\
\text { more than Half of } \\
\text { what I used to get } \\
\text { in the past }\end{array}$ & & & & & & & & & & & & & & \\
\hline $\begin{array}{c}\text { Affect productivity } \\
\text { and income by half } \\
\text { or less }\end{array}$ & 3 & 21.4 & 4 & 7.8 & 17 & 28.3 & 15 & 27.3 & 12 & 13.2 & 12 & 32.4 & 63 & 20.5 \\
\hline $\begin{array}{l}\text { Affect productivity } \\
\text { insignificantly }\end{array}$ & 4 & 28.6 & 10 & 19.6 & 18 & 30.0 & 16 & 29.1 & 28 & 30.8 & 12 & 32.4 & 88 & 28.6 \\
\hline Total & 14 & 100.0 & 51 & 100.0 & 60 & 100.0 & 55 & 100.0 & 91 & 100.0 & 37 & 100.0 & 308 & 100.0 \\
\hline
\end{tabular}

Table 3. ISO recommended work load and average work rest ratio

\begin{tabular}{|c|c|c|c|c|}
\hline Work intensity & $\begin{array}{c}\text { Light work in } \\
\text { WBGT in } \\
\text { degrees Celsius }\end{array}$ & $\begin{array}{c}\text { Medium work } \\
\text { WBGT degrees } \\
\text { Celsius }\end{array}$ & $\begin{array}{c}\text { Heavy work } \\
\text { WBGT degrees } \\
\text { Celsius }\end{array}$ & $\begin{array}{c}\text { Very heavy } \\
\text { work WBGT } \\
\text { degrees Celsius }\end{array}$ \\
\hline $\begin{array}{c}0 \% \text { rest/hour } \\
\text { continuous work }\end{array}$ & 31 & 28 & 27 & 25.5 \\
\hline $25 \%$ rest/hour & 31.5 & 29 & 27.5 & 26.5 \\
\hline $50 \%$ rest/hour & 32 & 30.5 & 29.5 & 28 \\
\hline $75 \%$ rest/hour & 32.5 & 32 & 31.5 & 31 \\
\hline $\begin{array}{c}100 \% \text { rest/hour } \\
\text { no activity }\end{array}$ & 39 & 37 & 36 & 34 \\
\hline
\end{tabular}

\section{Discussion}

The rainy season in the study area normally commences in April, however, there has been a shifting trend for rain to arrive later in the year at May-June (Laux et al., 2008). This has increased the length of the dry season, thus contributing to an increase in temperature in the region (Laux et al., 2008). Extreme temperatures and droughts are predicted to increase in the near future (EPA, 2007; Van de Giesen, Liebe, \& Jung, 2010). The farm workers in this vicinity are from the poorest threshold in Ghana (Webber, 1996; Whitehead, 2006) and cannot afford mechanical agriculture. Like their other counterparts in Africa, muscular energy is the predominant form used to undertake farm activities (Food and Agriculture Organization, 1987). The farm work is strenuous and climate change will intensify farmers' exposure to environmental heat. This study has shown that over 5 hours in a day are estimated to be above $26^{\circ} \mathrm{C}$ WBGT, while 6 hours in a day are estimated to be over $30^{\circ} \mathrm{C}$ WBGT in the month of March, April, and June. The ISO 7243 resting requirement was not applied as farmers rest opportunitically and generally aimed to get the work done. As such there was a potential influence on health effects regarding the state of insufficient rest on sustainable health. A large number of farmers engaged in heavy and very heavy work like cutting of trees with cutlasses and digging holes to get water for irrigating their crops because of inadequate rains. On their concern of heat to their health in all age group $93.5 \%$ expressed concern of heat to their health while $49 \%$ of the entire age group expressed that the increase in heat has affected their income much more than half of what they used to get in the previous years. This study is consistent with that on heat exposure impacts on rice harvesters in India (Sahu, Sett, \& Kjellstrom, 2013). The fulcrum of this study is to present level of heat stress on outdoor farmers and its impacts on work output as climate change increased. Heavy and very heavy work (Table 3) is likely to become difficult and health threatening in the wake of increased temperature if adequate rests are not observed. However, hourly output with series of rest in such manual task like digging, cutting of trees, hand fetched water from boreholes to irrigate crops which fall in the 
zone of heavy and very heavy ISO7243 in heat prone environment will be undermined. The estimation of reduction in work output and productivity of manual farm work as heat increases in developing countries and poor environment such as Northern Ghana is a critical aspect of climate change impact assessment. This calls for the need of appropriate measure to improve work capacity, health and sustainable farming as climate change is intensified. Studies have shown that work productivity of farmers working in heat environments deceases as heat increases (Sahu et al., 2013).

From both historical trends and these study results, temperatures are usually at highest during the months of March and April in Bawku East and that clearly affects WBGT. The inland topography of Bawku East may be a key factor related to the high temperature in the area, since inland areas in the tropics have higher temperatures compared to coastal areas which tend to experience seabreezes (IPCC, 2007). In order to protect farmers in the rural communities of Bawku East, appropriate ISO 7243 work/rest schedules need to be implemented, especially when heavy and very heavy manual labor is being performed. Continuous work for many hours without rest is likely to affect farmers' health which would in turn impact on the sustainability of farming in the region. Knowledge about work and rest regimes should be disseminated to farmers in the form of frequent education in rural communities. This will enhance their knowledge to protect their health especially when extreme climatic conditions are predicted to worsen in the vicinity. The establishment of a heat monitoring service must be implemented and when the situation requires implementation of precautionary work/rest regimes this information needs to be conveyed to farmers through appropriate means. In the longer term, the provision of adequately ventilated housing and shelter out of the sun in the fields should be provided. A central air conditioned resting place with cool potable water should be provided where farmers can cool down when necessary. Improvements in the current irrigation system will enable farmers to obtain water for irrigation eliminating the need to dig bore holes and draw water manually.

\section{Conclusion}

Despite the physiological benefits by acclimatization of a person in a working environment coupled with implementation of heat stress intervention, heat stress related illnesses are still prevalent in many occupational settings. This attests to the need for further heat stress measurements and research to be intensified in occupations susceptible to heat stress (Maté \& Oosthuizen, 2011). There is an association between climate change and sustainable development issues with regard to health, food security, employment, income, and livelihood. These are largely affected by the impact of high temperature especially when such activities are carried out in outdoor environment (Lundgren, Kuklane, Gao, \& Holmér, 2013). The current policies in agricultural sector in Ghana do not make room for health protection for farmers who spend many hours in the sun. This is significant issue in the context of sustainable farming as temperature are predicted to increase globally (IPCC, 2007a), and in northern Ghana specifically (EPA, 2007).

Modification of the task in outdoor farming in Bawku East and other part of rural Ghana is imperative in the emergence of global warming and climate change. Manual labor which forms the predominant way of farming in African region needs to be replaced by mechanical farming where machines could be used for weeding, digging and harvesting. In this way the number of hours a person will spend in the outdoors under the direct exposure of hot sun will be reduced. Concern about heat impacts on health and productivity will be well managed as global warming is intensified.

The measurement of heat stress in the farming communities where the study took place serves as a prelude for deeper investigation with different heat measuring equipment.and longer measurements. The exposure level measured with alternative heat measuring device can attest to the gravity of heat exposure to rural communities in the developing world such as Bawku East. Moreover, quantification of farm work productivity and level of WBGT in each hour in several areas of manual task environment will assist in the progress of estimating climate change impact on poor and developing countries whose farmers work manually in exposure of heat and other weather hazards. The WBGT above 26 degrees affects work pace and productivity. Local economy will be massively affected when heat is increased because of climate change. Sustainable adaptation with the help of government and nongovernmental organization on better ways to confront environmental heat exposure is timely and appropriate at rural Ghana in this period of global warming and climate change.

\section{References}

Bethea, N., Bobo, M., \& Ayoub, M. (1980). The Physiological Responses to Low Coal Mining. Paper presented at the Proceedings of the Human Factors and Ergonomics Society Annual Meeting.

Bridger, R. S. (Ed.). (2003). Introduction to ergonomics (2nd ed.). London: tailor and Francis. 
Climate vulnerability monitor. (2012). Climate vulnerability monitor, (2nd ed.) of Ghana report. Retrieved from http://daraint.org/climate-vulnerability-monitor/climate-vulnerability-monitor-2012/country-study-ghana/ at 11:47 AWST

Coris, E. E., Ramirez, A. M., \& Van Durme, D. J. (2004). Heat illness in athletes. Sports Medicine, 34(1), 9-16. http://dx.doi.org/10.2165/00007256-200434010-00002

Donoghue, A. M., Sinclair, M. J., \& Bates, G. P. (2000). Heat exhaustion in a deep underground metalliferous mine. Occupational and environmental medicine, 57(3), 165-174. http://dx.doi.org/10.1136/oem.57.3.165

Ebi, K. L., Smith, J. B., \& Burton, I. (2006). Integration of public health with adaptation to climate change: lessons learned and new directions: CRC Press.

EPA. (2007). Climate Change and Ghanian Economy (Vol. 1). Accra: Environmental Protection Agency of Ghana.

Food and Agriculture Organization. (1987). African Agriculture: The next 25 years. Rome: FAO.

Frimpong, K., Van Etten, E. J., \& Oosthuizen, J. (2014). Recent trends in temperature and relative humidity in Bawku East of northern Ghana. Journal of Geography and Geology.

Haines, A., Kovats, R. S., Campbell-Lendrum, D., \& Corvalán, C. (2006). Climate change and human health: impacts, vulnerability and public health. Public health, 120(7), 585-596. http://dx.doi.org/10.1016/j.puhe.2006.01.002

IPCC. (2007a). Climate change 2007 impacts, adaptation and vulnerability. contribution of working group two to fourth assessment report of the IPCC. UK.

IPCC. (2007b). Climate Change 2007: The physical Science Basis. Contribution of working Group 1 to fourth assessment report of the intergovernmental Panel on Climate Change. New York: Cambridge University Press.

ISO. (1989). ISO 7243: Hot Environments-Estimation of the Heat Stress on Working Man, Based on the WBGT-index (Wet Bulb Globe Temperature) (pp. 368-379). Geneva: International Standard Organization.

Kjellstrom, T. (2000). Climate change, heat exposure and labour productivity. Paper presented at the Epidemiology.

Kjellstrom, T. (2009). Climate change, direct heat exposure, health and well-being in low and middle-income countries. Global Health Action, 2.

Kjellstrom, T., Butler, A. J., Lucas, R. M., \& Bonita, R. (2010). Public health impact of global heating due to climate change: potential effects on chronic non-communicable diseases. International journal of public health, 55(2), 97-103. http://dx.doi.org/10.1007/s00038-009-0090-2

Kjellstrom, T., Gabrysch, S., Lemke, B., \& Dear, K. (2009). The 'Hothaps' programme for assessing climate change impacts on occupational health and productivity: An invitation to carry out field studies. Global Health Action, 2.

Kjellstrom, T., Holmer, I., \& Lemke, B. (2009). Workplace heat stress, health and productivity-an increasing challenge for low and middle-income countries during climate change. Global Health Action, 2.

Kjellstrom, T., Kovats, R. S., Lloyd, S. J., Holt, T., \& Tol, R. S. (2009). The direct impact of climate change on regional labor productivity. Archives of Environmental \& Occupational Health, 64(4), $217-227$. http://dx.doi.org/10.1080/19338240903352776

Kjellstrom, T., Lemke, B., \& Otto, M. (2013). Mapping Occupational Heat Exposure and Effects in South-East Asia: Ongoing Time Trends 1980-2011 and Future Estimates to 2050. Industrial Health, 51(1), 56-67. http://dx.doi.org/10.2486/indhealth.2012-0174

Laux, P., Kunstmann, H., \& Bárdossy, A. (2008). Predicting the regional onset of the rainy season in West Africa. International Journal of Climatology, 28(3), 329-342. http://dx.doi.org/10.1002/joc.1542

Leithead, C. S., \& Lind, A. R. (1964). Heat Stress and Heat Disorders.

Lemke, B., \& Kjellstrom, T. (2012). Calculating workplace WBGT from meteorological data: a tool for climate change assessment. Industrial Health, 50(4), 267-278. http://dx.doi.org/10.2486/indhealth.MS1352

Lundgren, K., Kuklane, K., Gao, C., \& Holmér, I. (2013). Effects of heat stress on working populations when facing climate change. Industrial Health, 51(1), 3-15. http://dx.doi.org/10.2486/indhealth.2012-0089 
Maté, J., \& Oosthuizen, J. (2011). Global Warming and Heat Stress Among Western Australian Mine, Oil and Gas Workers.

McSweeney, C. N. M. L. G. (2012). UNDP Climate Change Profiles: Ghana. UNDP.

Nybo, L. (2008). Hyperthermia and fatigue. Journal of Applied Physiology, 104(3), 871-878. http://dx.doi.org/10.1152/japplphysiol.00910.2007

Occupational Safety and Health Admnistration (OSHA). (1999). Heat stress. Washington, DC:, OSHA Technical Office for Science and Technology assessment.

Parsons, K. C. (2003). Human thermal environments: the effects of hot, moderate, and cold environments on human health, comfort, and performance: CRC Press.

Pradhan, B., Shrestha, S., Shrestha, R., Pradhanang, S., Kayastha, B., \& Pradhan, P. (2013). Assessing climate change and heat stress responses in the tarai region of Nepal. Industrial Health, 51(1), 101-112. http://dx.doi.org/10.2486/indhealth.2012-0166

Sahu, S., Sett, M., \& Kjellstrom, T. (2013). Heat Exposure, Cardiovascular Stress and Work Productivity in Rice Harvesters in India: Implications for a Climate Change Future. Industrial Health, 51(4), 424-431. http://dx.doi.org/10.2486/indhealth.2013-0006

US Army center for Health Promotion and Preventive Medicine USACHPPM. (2003). Heat stress control and heat casualty management (TB MED507/AFPAM 48-152). Aberdeen Proving Ground, Mid, US.

Van de Giesen, N., Liebe, J., \& Jung, G. (2010). Adapting to climate change in the Volta Basin, West Africa. Current science, 98(8), 1033-1037.

Webber, P. (1996). Agrarian change in Kusasi, north-east Ghana. Africa, 437-457. http://dx.doi.org/10.2307/1160961

Whitehead, A. (2006). Persistent poverty in north east Ghana. The Journal of Development Studies, 42(2), 278-300. http://dx.doi.org/10.1080/00220380500405410

\section{Copyrights}

Copyright for this article is retained by the author(s), with first publication rights granted to the journal.

This is an open-access article distributed under the terms and conditions of the Creative Commons Attribution license (http://creativecommons.org/licenses/by/3.0/). 